\title{
HUBUNGAN MOTIVASI KERJA DENGAN PERILAKU PENGGUNAAN ALAT PELINDUNG DIRI PADA PETUGAS SAMPAH MEDIS DI RSU BANGLI
}

\author{
Putu Dewi Nara Santi ${ }^{1}$, I Nyoman Gede Suyasa ${ }^{2}$, I Wayan Jana ${ }^{3}$
}

\begin{abstract}
Hospital health facilities, is a workplace that is heavily loaded with potential health and safety hazards of its workers. The risk of health problems and accidents becomes greater because health facilities are labor-intensive workplaces. The purpose of this study to determine the relationship of work motivation with the behavior of the use of personal protective equipment (PPE) to medical waste officers at Bangli General Hospital. The type of this research is observational research with cross sectional approach implemented in Bangli General Hospital, with 36 respondents. Data were collected by using questionnaire and univariate and bivariate analysis. Result of this research, there are $25 \%$ resonden have low motivation and as many as $27,8 \%$ of respondent have behavior of usage of PPE which is not good. The result of bivariate analysis shows that there is a significant correlation between work motivation and the behavior of PPE usage ( $p$ value 0,003) with medium relationship level 0,448. The conclusion is that there is a significant correlation between work motivation and the behavior of PPE usage on medical waste officer in Bangli General Hospital.
\end{abstract}

Keywords: Motivation, Behavior, PPE

\begin{abstract}
Abstrak : Fasilitas kesehatan rumah sakit, merupakan tempat kerja yang sangat sarat dengan potensi bahaya kesehatan dan keselamatan pekerjanya. Risiko terjadinya gangguan kesehatan dan kecelakaan menjadi semakin besar mengingat fasilitas kesehatan merupakan tempat kerja yang padat tenaga kerja. Tujuan penelitian ini untuk mengetahui hubungan motivasi kerja dengan perilaku penggunaan alat pelindung diri pada petugas sampah medis di RSU Bangli. Jenis penelitian ini adalah penelitian observasional dengan pendekatan cross sectional yang dilaksanakan di RSU Bangli, dengan jumlah responden sebanyak 36 orang. Pengumpulan data dilakukan dengan menggunakan kuisioner dan dilakukan analisis univariat dan bivariat. Hasil penelitian ini, terdapat $25 \%$ resonden memiliki motivasi yang rendah dan sebanyak $27,8 \%$ responden memiliki perilaku penggunaan APD yang tidak baik. Hasil analisis bivariat menunjukkan ada hubungan yang signifikan antara motivasi kerja dengan perilaku penggunaan APD (nilai $p$ 0,003) dengan tingkat hubungan sedang sebesar 0,448. Kesimpulan yang didapat adalah ada hubungan yang signifikan antara motivasi kerja dengan perilaku penggunaan APD pada petugas sampah medis di RSU Bangli.
\end{abstract}

Kata Kunci : Motivasi, Perilaku, APD

Industri pelayanan kesehatan berpengaruh pada kesejahteraan

merupakan sektor penting yang masyarakat. Seiring berjalannya 
pemikiran manajemen, pendekatan pemikiran bisnis mengarah pada konsep supply chain manajemen. Pengelolaan yang dilakukan industri harus menyeluruh, melihat semua stakeholder yang sering terkait dalam ragkaian supply chain. Hal tersebut sangat penting dalam memastikan tingginya standar pelayanan, serta menjaga kepuasan para pengelola dan pada saat yang bersamaan tetap menjaga keselamatan pasien dan juga tenaga kesehatan(1)

Fasilitas pelayanan kesehatan adalah suatu tempat yang digunakan untuk menyelenggarakan upaya pelayanan kesehatan, baik promotif, preventif, kuratif serta rehabilitatif yang dilakukan oleh pemerintah daerah dan masyarakat(2). Fasilitas kesehatan, termasuk di dalamnya adalah rumah sakit, merupakan tempat kerja yang sangat sarat dengan potensi bahaya kesehatan dan keselamatan pekerja. Risiko terjadinya gangguan kesehatan dan kecelakaan menjadi semakin besar mengingat fasilitas kesehatan merupakan tempat kerja yang padat tenaga kerja. Berbagai penelitian menunjukan bahwa prevalensi gangguan kesehatan yang terjadi di fasilitas kesehatan rumah sakit lebih tinggi dibandingkan tempat kerja lainnya(3)

Rumah sakit sebagai industri jasa merupakan sebuah industri yang mempunyai beragam persoalan tenaga kerja yang rumit dengan berbagai risiko terkena penyakit akibat kerja bahkan kecelakan akibat kerja sesuai jenis pekerjaannya, sehingga berkewajiban menerapkan upaya Keselamatan dan Kesehatan Kerja di Rumah Sakit (K3RS). Pelaksanaan Kesehatan dan Keselamatan Kerja (K3) adalah salah satu bentuk upaya untuk menciptakan tempat kerja rumah sakit yang aman, sehat, bebas dari pencemaran lingkungan, sehingga dapat mengurangi dan atau bebas dari kecelakaan kerja dan penyakit akibat kerja yang pada akhirnya dapat meningkatkan efisiensi dan produktivitas kerja(4).

Tahun 2012, ILO mencatatat angka kematian yang disebabkan oleh KK dan PAK sebanyak 2 juta kasus setiap tahun (Kepmenkes RI, 2014). Ancaman kecelakaan kerja di tempat kerja di negara berkembang seperti Indonesia masih sangat tinggi. Hasil laporan National Safety 
Council tahun 1988 menunjukkan bahwa terjadinya kecelakaan kerja di rumah sakit $41 \%$ lebih besar dari pekerja industri lainnya. Kasus yang sering terjadi adalah tertusuk jarum, terkilir, sakit pinggang, tergores, luka bakar dan penyakit infeksi lainnya(5).

Berdasarkan data-data yang ada insiden akut secara signifikan lebih besar terjadi pada pekerja rumah sakit dibandingkan dengan seluruh pekerja dilihat dari jenis kelamin, ras, umur, dan status pekerjaan. Pekerja rumah sakit berisiko 1,5 kali lebih besar dari golongan lain. Probabilitas penularan HIV setelah luka tusuk jarum suntik yang terkontaminasi HIV 4 : 1000. Risiko penularan $\mathrm{HCV}$ setelah luka tusuk jarum suntik yang mengandung $\mathrm{HCV}$ 3-100 (Kepmenkes RI, 2010). Berdasarkan insiden yang ada, bentuk upaya perlindungan yang dapat dilakukan adalah dengan menggunakan Alat Pelindung Diri (APD). Menurut Peraturan Menteri Tenaga Kerja Dan Transmigrasi RI Nomor 8 Tahun 2010 Tentang Alat Pelindung Diri, APD adalah suatu alat yang mempunyai kemampuan untuk melindungi seseorang yang fungsinya mengisolasi sebagian atau seluruh tubuh dari potensi bahaya di tempat kerja.

Pihak rumah sakit harus mencari cara untuk mendorong para karyawannya untuk mempunyai kemauan dalam bekerja untuk mencapai tujuan dari penerapan K3 di rumah sakit, dan cara yang dapat dilakukan adalah dengan memotivasi para karyawannya. Pada penelitian terdahulu didapatkan bahwa disisi lain sikap kerja yang kurang baik bisa timbul karena rendahnya motivasi kerja. Sehingga masalah sikap kerja ini juga dapat memengaruhi kinerja karyawan dalam memberikan pelayanan kepada konsumen sehingga keluhan dari konsumen muncul dan bahkan dapat merugikan diri karyawan itu sendiri(6).

Oleh sebab itu, motivasi kerja disebut sebagai pendorong semangat kerja. Kuat dan lemahnya motivasi kerja seorang tenaga kerja ikut menentukan besar kecilnya kinerja karyawan. Sikap kerja yang baik merupakan salah satu faktor yang penting agar kinerja dapat berjalan secara optimal. Sikap yang dimaksud adalah sikap karyawan dalam 
menjaga keselamatan kerjanya saat melaksanakan suatu pekerjaan atau kegiatan(7).

Berdasarkan studi pendahuluan di RSU Bangli, sebagian besar petugas cleaning service (CS) yang bertugas mengangkut sampah medis bekerja tanpa menggunakan alat pelindung diri yang lengkap. Seperti tidak menggunakan handscoun dan celemek. Pihak petugas K3RS juga telah melakukan komunikasi, informasi, dan edukasi (KIE) pada petugas CS, namun pelaksanaan dari petugas CS masih kurang. Menurut hasil wawancara yang telah dilakukan, petugas CS tersebut malas untuk menggunakan APD yang telah disiapkan. Sedangkan sampah yang diangkut merupakan sampah medis infeksius dan benda tajam yang berpotensi mengenai petugas jika tidak berhati-hati saat pengangkutan.

\section{Metode}

Jenis penelitian yang akan dipergunakan oleh peneliti adalah observasional dengan metode cross sectional. Sampel dari penelitian ini adalah petugas yang menangani sampah medis di RSU Bangli sebanyak 36 orang. Sampel dalam penelitian di ambil dari seluruh populasi mengingat apabila subjek penelitian kurang dari 100, maka seluruh populasi diambil sebagai sampel sehingga penelitian ini merupakan penelitian populasi. Teknik penentuan sampel yang digunakan dalam penelitian ini adalah non probability sampling merupakan sampling jenuh yang menggunakan teknik penarikan sampel bila semua anggota populasi digunakan sebagai sampel. Cara pengumpulan data yaitu melalui wawancara kepada responden dengan menggunakan kuisioner ditiap variabel untuk mengetahui hasil penelitian yang didapatkan, serta observasi dilakukan untuk mengetahui tindakan yang dilakukan responden sesuai kuesioner. 


\section{Hasil Penelitian}

1. Motivasi kerja responden

Tabel 1

Distribusi Responden Berdasarkan

Motivasi Kerja Pada Petugas Sampah

Medis di RSU Bangli Tahun 2018

\begin{tabular}{ccc}
\hline Motivasi Kerja & Frekuensi & $\mathbf{\%}$ \\
\hline Tinggi & 27 & 75 \\
Rendah & 9 & 25 \\
\hline Jumlah & $\mathbf{3 6}$ & $\mathbf{1 0 0}$
\end{tabular}

Pengukuran motivasi kerja ini dilakukan pada petugas sampah medis yaitu dengan mengukur tingkat motivasi kerja responden yang diperoleh dari jawaban responden pada kuesioner.

Berdasarkan hasil penelitian motivasi kerja responden dibagi menjadi dua tingkatan yaitu tinggi dan rendah. Hasil penelitian tersebut menjelaskan bahwa sebanyak $75 \%$ responden mempunyai motivasi kerja yang tinggi.
2. Perilaku penggunaan APD responden Tabel 2

Distribusi Responden Berdasarkan

Perilaku Penggunaan APD Pada

Petugas Sampah Medis di RSU

Bangli Tahun 2018

\begin{tabular}{ccc}
\hline Kriteria Perilaku & Frekuensi & $\mathbf{\%}$ \\
\hline Baik & 26 & 72,2 \\
Tidak Baik & 10 & 27,8 \\
\hline Jumlah & $\mathbf{3 6}$ & $\mathbf{1 0 0}$ \\
\hline
\end{tabular}

Pengukuran perilaku dalam penelitian ini dilakukan pada petugas sampah medis dengan mengukur menggunakan kuisioner tentang perilaku responden tentang penggunaan APD dan diperoleh jawaban atas pertanyaan pada kuisioner. Berdasarkan hasil penelitian perilaku dibagi menjadi tiga bagian yaitu pengetahuan, sikap, dan tindakan dengan kategori yaitu baik dan tidak baik. Hasil penelitian tersebut menjelaskan bahwa sebanyak $72,2 \%$ responden memiliki perilaku penggunaan APD yang baik. 
3. Analisis hubungan motivasi kerja dengan perilaku penggunaan alat pelindung diri Tabel 3

Hubungan Motivasi Kerja Dengan Perilaku Penggunaan Alat Pelindung Diri Pada Petugas Sampah Medis di RSU Bangli Tahun 2018

\begin{tabular}{|c|c|c|c|c|c|c|c|c|}
\hline \multirow{3}{*}{$\begin{array}{c}\text { Motivasi } \\
\text { Kerja }\end{array}$} & \multicolumn{4}{|c|}{ Perilaku Penggunaan APD } & \multirow{2}{*}{\multicolumn{2}{|c|}{ Total }} & \multirow{3}{*}{$\begin{array}{c}\text { Nilai } \\
\qquad p\end{array}$} & \multirow{3}{*}{$\mathrm{CC}$} \\
\hline & \multicolumn{2}{|c|}{ Baik } & \multicolumn{2}{|c|}{ Tidak Baik } & & & & \\
\hline & $\mathbf{f}$ & $\%$ & $\mathbf{F}$ & $\%$ & $\mathbf{f}$ & $\%$ & & \\
\hline Tinggi & 23 & 85,2 & 4 & 14,8 & 27 & 100 & \multirow{2}{*}{0,003} & \multirow{2}{*}{0,448} \\
\hline Rendah & 3 & 33,3 & 6 & 66,7 & 9 & 100 & & \\
\hline Jumlah & 26 & 72,2 & 10 & 27,8 & 36 & 100 & & \\
\hline
\end{tabular}

Berdasarkan hasil tabulasi diketahui sebanyak 27 responden yang memiliki motivasi kerja yang tinggi, 23 orang atau 85,2 \% diantaranya memiliki perilaku penggunaan APD yang baik dan 4 orang atau 14,8\% memiliki perilaku penggunaan APD yang tidak baik. Sebanyak 9 responden yang memiliki motivasi kerja yang rendah, 3 orang atau 33,3 \% memiliki perilaku penggunaan APD yang baik dan 6 orang atau 66,7 \% memiliki perilaku penggunaan APD yang tidak baik. Dari semua responden yang memiliki motivasi kerja yang tinggi, lebih banyak memiliki perilaku penggunaan APD yang baik daripada yang tidak baik.

Nilai $\mathrm{p}$ yang diperoleh dengan uji pearson chi square untuk asymp.sig (2-sided) adalah 0,003 atau nilai $p<0,05$ maka, Ha diterima, yang artinya ada hubungan yang singnifikan antara motivasi kerja dengan perilaku penggunaan alat pelindung diri pada petugas sampah medis dengan nilai CC (Coefficient Contingency) $\quad 0,448$ yaitu dengan tingkat hubungan sedang. 


\section{Pembahasan}

1. Motivasi kerja responden

Pengukuran variabel motivasi kerja pada penelitian ini dilakukan dengan menggunakan kuisioner pada 36 responden dengan jumlah pertanyaan sebanyak 9 pertanyaan. Berdasarkan hasil dari penelitian didapatkan bahwa skor tertinggi untuk penilaian motivasi kerja yang telah dijawab oleh petugas sampah medis yaitu 8 (delapan) dan skor terendah yang dijawab yaitu 4 (empat)

Hasil yang telah didapat menggambarkan motivasi kerja yang dimiliki responden tergolong baik. Namun, banyak responden yang masih khawatir akan kecelakaan kerja yang disebabkan oleh sampah medis. Hal tersebut dikarenakan reponden tidak memiliki jaminan kesehatan yang diberikan pihak rumah sakit. Kurangnya pelatihan yang diberikan kepada responden juga mengakibatkan kurangnya pemahaman tentang K3 serta motivasi yang kurang akan mempengaruhi produktifitas kerja responden. Motivasi kerja adalah kekuatan yang mendorong seseorang karyawan yang menimbulkan dan mengarahkan perilaku karyawan(8).

2. Perilaku penggunaan APD responden

Pengukuran variabel perilaku penggunaan APD pada penelitian ini dilakukan dengan menggunakan kuisioner pada 36 responden dengan jumlah pertanyaan sebanyak 23 pertanyaan. Berdasarkan hasil penelitian didapatkan bahwa skor tertinggi untuk penilaian perilaku penggunaan APD pada petugas sampah medis yaitu 22 (dua puluh dua) dan skor terendah yaitu 10 (sepuluh).

Hasil tersebut menggambarkan bahwa perilaku responden tentang penggunaan APD adalah baik. Namun masih ada responden yang tidak memakai APD dengan baik. Perilaku merupakan hasil hubungan antara perangsang (stimulus) dan respon. Perilaku seseorang dapat dilihat dari pengetahuan, sikap, serta tindakan dalam melaksanakan suatu pekerjaan(9).

3. Hubungan motivasi kerja dengan perilaku penggunaan alat pelindung diri

Sebanyak 27 responden yang memiliki motivasi kerja yang tinggi dengan 4 orang atau $14,8 \%$ memiliki 
perilaku penggunaan APD yang tidak baik. Sebanyak 9 responden yang memiliki motivasi kerja yang rendah, 6 orang atau 66,7 \% memiliki perilaku penggunaan APD yang tidak baik. Hasil pengolahan data dari penelitian ini diperoleh nilai $p$ dengan uji pearson chi square untuk asymp.sig (2-sided) adalah 0,003 atau nilai $p<0,05$ maka Ha diterima, yang artinya ada hubungan yang singnifikan antara motivasi kerja dengan perilaku penggunaan alat pelindung diri pada petugas sampah medis dengan nilai CC (Coefficient Contingency) 0,448 yaitu dengan tingkat hubungan sedang.

Motivasi kerja disebut sebagai pendorong semangat kerja setiap tenaga kerja. Kuat dan lemahnya motivasi kerja seseorang tenaga kerja ikut menentukan besar kecilnya kinerja tenaga kerja. Perilaku kerja yang baik merupakan salah satu faktor yang penting agar kinerja dapat berjalan secara optimal. Perilaku yang dimaksud adalah perilaku kerja dalam menjaga keselamatan kerjanya saat melaksanakan suatu pekerjaan atau kegiatan. Perilaku merupakan hasil hubungan antara perangsang (stimulus) dan respon. Perilaku seseorang dapat dilihat dari pengetahuan, sikap, serta tindakan dalam melaksanakan suatu pekerjaan(7).

Penelitian oleh Wijayanto (2015)(10), kesimpulan yang didapatkan dari penelitiannya adalah ada hubungan motivasi dengan perilaku pemakaian APD, serta dengan kategori lemah. Dalam penelitian tersebut menjelaskan bahwa motivasi dipengaruhi oleh meningkatnya usia seseorang sehingga diharapkan dapat menerima informasi yang baik untuk meningkatkan pengetahuan dan berperilaku yang baik.

Hasil penelitian ini juga diperkuat oleh penelitian Kasim (2017)(11) yang menunjukan bahwa 34 responden $(81,0 \%)$ yang memiliki motivasi baik, dengan 1 responden $(2,4 \%)$ yang memiliki kepatuhan penggunaan APD yang kurang. Sedangkan reponden yang memiliki motivasi kurang sebanyak 3 responden $(7,1 \%)$ yang tidak patuh menggunakan APD, serta sebanyak 4 responden $(9,5 \%) \quad$ memiiliki kepatuhan penggunaan APD. Berdasarkan hasil uji statistik 
penelitian tersebut dapat dikatakan bahwa adanya hubungan yang signifikan antara motivasi dengan kepatuhan dalam penggunaan APD. Kepatuhan penggunaan APD merupakaan perilaku yang baik dalam mentaati penggunaan APD. Motivasi dan perilaku merupakan hal yang berbanding lurus dalam arti semakin tinggi motivasi yang ada didalam diri petugas maka akan semakin baik pula perilakunya.

Berdasarkan hasil yang didapat, petugas yang menangani sampah medis di RSU Bangli masih banyak yang berpendidikan SMA. Hasil observasi dilapangan didapatkan bahwa responden sangat membutuhkan perhatian dalam hal bimbingan dan pengawasan dalam pengelolaan sampah medis. Faktor motivasi cukup kuat berperan dalam mempengaruhi perilaku seseorang, termasuk perilaku petugas sampah medis dalam menggunakan alat pelindung diri yang sesuai dengan SOP rumah sakit. Selain memotivasi diri sendiri, motivasi atasan juga sangat diperlukan untuk memberikan perhatian dan semangat pada petugas untuk memakai APD saat bekerja.

\section{Simpulan}

1. Motivasi kerja responden petugas sampah medis di RSU Bangli tergolong tinggi dengan jumlah pekerja yang mempunyai motivasi kerja tinggi paling banyak yaitu sebanyak 27 orang atau $75 \%$.

2. Perilaku penggunaan APD pada petugas sampah medis di RSU Bangli tergolong baik dengan jumlah responden yang mepunyai perilaku penggunaan APD yang baik paling banyak yaitu 26 orang atau 72,2\%.

3. Ada hubungan yang signifikan antara motivasi kerja dengan perilaku penggunaan APD petugas sampah medis dengan nilai $p$ yaitu 0,003 dan nilai CC 0,448 yaitu tingkat hubungan sedang.

\section{Saran}

1. Untuk rumah sakit

Perlu ditingkatkan pemantauan, penyuluhan, dan pembinaan $\mathrm{K} 3$ untuk petugas sampah medis khususnya mengenai pentingnya pemakaian alat pelindung diri serta perlu penyediaan jaminan kesehatan bagi petugas sampah medis.

2. Untuk petugas sampah medis

Petugas sampah medis diharapkan lebih meningkatkan pengetahuan dan 
kesadaran akan pentingnya pemakaian alat pelindung diri pada

\section{Daftar Pustaka}

1. Lestari Y. Industri Pelayanan

Kesehatan. J Ilm. 2013;2.

2. RI. K. 1 Orang Pekerja Meninggal

Setiap 15 Detik Karena Kecelakaan

Kerja [Internet]. Depkes RI Website.

2014 [cited 2018 Jan 12]. Available

from:

http://www.depkes.go.id/pdf.php?id= 201411030005

3. Mauliku NE. Kajian Analisis

Penerapan Sistem Manajemen K3RS

Di Rumah Sakit Immanuel Bandung.

J Kesehat Kartika. 2011;36.

4. Maria S. Kejadian Kecelakaan Kerja

Perawat Berdasarkan Tindakan

Tidak Aman. J Care. 2015;3(2):10-1.

5. Sholihah QD. K3 RS

Meminimalisasi Kecelakaan Dan

Penyakit Akibat Kerja Di Rumah

Sakit. Malang: Universitas Brawijaya

Press.; 2013.

6. Subakti AG. Pengaruh Motivasi,

Kepuasan, Dan Sikap Kerja

Terhadap Kinerja Karyawan Di Cafe

X Bogor. Binus Bus Rev.

2013;4(2):596-606.

7. Anoraga P. Psikologi Kerja. Jakarta: saat bekerja untuk keselamatan dan kesehatan kerja diri

Rineka Cipta; 2006.

8. Gibson D. Organisasi.

Jakarta: Binarupa Aksara;

2013.

9. Kholid A. Promosi

Kesehatan : Dengan

Pendekatan Teori Perilaku,

Media, dan Aplikasinya.

Jakarta: Rajawali Pers; 2014.

10. Wijayanto W. Hubungan

Motivasi Perawat Dengan

Perilaku Pemakaian Alat

Pelindung Diri Saat

Melakukan Kemoterapi Di

Ruang Rawat Inap RSUD

DR. Moewardi. J Ilm.

2015;5-8.

11. Kasim YD. Hubungan

Motivasi \& Supervisi Dengan

Kepatuhan Perawat Dalam

Penggunaan Alat Pelindung

Diri (APD) Pada Penanganan

Pasien Gangguan

Muskuloskeletal Di IGD

RSUP Prof. DR. R. D.

Kandou Manado. E-Journal

Keperawatan. 2017;5(1):5-6. 